\title{
Near real time detection of deforestation in the Brazilian Amazon using MODIS imagery \\ (doi:10.4136/ambi-agua.4)
}

\author{
Yosio E. Shimabukuro; Valdete Duarte; Liana O. Anderson; Dalton M. Valeriano; \\ Egídio Arai; Ramon M. de Freitas; Bernardo F. T. Rudorff; Maurício A. Moreira
}

Instituto Nacional de Pesquisas Espaciais (INPE)

Av. dos Astronautas, 1758, São José dos Campos, SP, 12227-010, Brasil

E-mail: \{yosio, valdete, liana, dalton, egidio, ramon, bernardo, mauricio\}@dsr.inpe.br

\begin{abstract}
The objective of this paper is to provide near real time information about deforestation detection (DETER) in the entire Brazilian Amazon using MODIS high temporal resolution images. It is part of the operational deforestation monitoring project to estimate the annual deforestation rate in the Brazilian Amazon (PRODES). A rapid deforestation detection method was designed to support land use policies in this region. In order to evaluate the proposed method a test site was selected covering a Landsat ETM+ scene (227/68) located in Mato Grosso State. For this purpose a multitemporal series of MODIS surface reflectance images (MOD09) and the corresponding ETM+ images from June to October 2002 were analyzed. It was found that small deforested areas (lower than $15 \mathrm{ha}$ ) were detected by MODIS images with lower accuracy when compared with ETM+ images. As the deforested areas increase MODIS and ETM+ results tend to converge. This procedure showed to be adequate to operationally detect and monitor deforested areas and has been used since 2004 as part of a government plan to control the Amazon deforestation.
\end{abstract}

Keywords: Deforestation; Brazilian Amazon; change detection; MODIS; spectral mixing model; fraction images.

\section{Detecção em tempo quase real de desflorestamento na Amazônia brasileira utilizando imagens MODIS}

\section{RESUMO}

O objetivo deste artigo é fornecer informação sobre a detecção em tempo real da área desflorestada (DETER - Detecção em Tempo Real do Desflorestamento na Amazônia Brasileira) utilizando imagens do MODIS de alta resolução temporal. O DETER é parte do projeto operacional que estima a taxa anual do desflorestamento na Amazônia Brasileira (PRODES - Projeto de Monitoramento do Desflorestamento na Amazônia). Um método para detecção rápida do desflorestamento foi delineado para dar suporte à fiscalização do uso da terra na região. A fim de avaliar o método proposto foi selecionada uma área teste que cobre uma cena do Landsat ETM+ (227/68) localizada no Estado do Mato Grosso. Para este propósito uma série multitemporal de imagens refletância de superfície do MODIS (MOD09) e de imagens ETM+ correspondentes ao período de junho a outubro de 2002 foi analisada. Foi verificado que pequenas áreas de desflorestamento (menores do que 15 ha) foram detectadas pelas imagens MODIS com menor acurácia quando comparado com as imagens do ETM+. À medida que as áreas desflorestadas aumentam os resultados do MODIS e do ETM+ tendem a convergir. Este procedimento mostrou ser adequado para detectar e monitorar 
operacionalmente as áreas desflorestadas e vem sendo utilizado pelo governo desde 2004 como parte do Plano de Ação para a Prevenção e Controle do Desmatamento na Amazônia Brasileira.

Palavras-chave: Desflorestamento; Amazônia Brasileira; detecção de mudança; MODIS; modelo de mistura espectral; imagens fração.

\section{INTRODUCTION}

Earth observation satellite images are commonly used to monitor land use and land cover changes to support environmental management policies and to assess global change processes (Townshend et al., 1991; DeFries et al., 1998; Bartholomé; Belward, 2005). Steady progress in space technology over the past decades continues to improve and increase remote sensing applications for a better understanding of Earth's dynamic cycles and the influence of human activities on the environment. One example of space technology progress is the Moderate Resolution Imaging Spectroradiometer (MODIS) sensor onboard of Terra and Aqua platforms launched, by NASA (National Aeronautics and Space Administration) in December 1999 and May 2002, respectively. The MODIS sensor was especially designed to allow frequent and accurate monitoring of Earth surface dynamic processes through the improvement of sensor spatial, spectral, temporal and radiometric characteristics of its precursor the AVHRR (Advanced Very High Resolution Radiometer) sensor on board of the TIROS-NOAA series of satellites since 1978 (Justice et al., 2002). Several geolocated products are generated from the MODIS sensor including the surface reflectance image (MOD09) that is mainly used for land surface analysis (Justice et al., 2002). This product is an estimate of the surface spectral reflectance as it would have been measured at ground level considering that there were no atmospheric scattering or absorption. This estimate is attained through the application of a MODIS atmospheric correction algorithm (Vermote et al., 2002).

The use of moderate spatial resolution (e.g. $250 \mathrm{~m}$ ) or low spatial resolution (e.g. $1 \mathrm{~km}$ ) sensor data implies in the so called "mixture problem", which means that the pixel value is a mixture of reflectance from different components within the pixel. Several techniques such as modeling and empirical estimations have been applied to depict subpixel heterogeneity in land cover from remotely sensed data (DeFries et al., 2000). Fraction images, derived from a Linear Spectral Mixing Model are an alternative approach to enhance the information of each component and to reduce image data dimensionality for digital image analysis and interpretation (Aguiar et al., 1999). These fraction images obtained from different remotely sensed data have been used to map vegetation cover in Amazônia (Aguiar et al., 1995), to monitor deforestation (Shimabukuro et al., 1998), land cover change (Carreiras et al., 2002), and vegetation classification (DeFries et al., 2000).

The procedure using the Landsat fraction images has been used operationally in the deforestation monitoring project (PRODES) to estimate the annual deforestation rate in the Brazilian Amazon which is carried out by the National Institute for Space Research (INPE, 2002). Since the PRODES information is obtained using low temporal resolution images (16 days, Landsat) restricting the acquisition of frequent cloud free image it is not possible to monitor the fast land cover changes that is required for official control of deforestation activities. Therefore, it is necessary to have an efficient and operational procedure to monitor the dynamic of the deforestation activity. Then, the objective of this paper is to provide near real time information about deforestation detection in the entire Brazilian Amazon using the MODIS high temporal resolution images. 


\section{MATERIAL AND METHODS}

\subsection{Study Area}

The study area for the DETER project is the entire Brazilian Amazon (Figure 1). In order to evaluate and validate the present procedure a test site in Mato Grosso State corresponding to a Landsat ETM+ scene (Path 227/Row 68) was selected (Figure 1). Eight cloud free ETM+ and MODIS images were concomitantly acquired during the critical deforestation period of 2002 (June through October). This test site might not be representative in terms of deforestation pattern for the entire Brazilian Amazon. However, it is located within a region of different vegetation type classes and various sizes of deforestation. Furthermore, the test site is within a region that achieved the highest deforestation rate in the year 2002 (INPE, 2002; Anderson et al., 2005). The main drivers of new deforestation activities are the increase of agricultural projects, mainly soybean plantation, cattle raising, and industrial logging that often do not respect the forest protection laws (Anderson et al., 2005).

\subsection{Near Real Time Deforestation Detection Procedure}

The procedure to detect deforestation areas in near real time with MODIS images is based on the PRODES project that uses Landsat Thematic Mapper (TM) data. The first step of this procedure consists on the application of a Linear Spectral Mixing Model to generate the fraction images of vegetation, soil, and shade. The next step is the image segmentation followed by an unsupervised classification by region. Finally, a manual edition of the unsupervised classification is performed on the computer screen (Shimabukuro et al., 1998).

a) Linear Spectral Mixing Model: is the image processing algorithm that generates the fraction images with the proportion of each component (vegetation, soil, and shade) inside the pixel which is estimated by minimizing the sum of squares of the errors. The proportion values must be nonnegative, and they also must add to unity (Shimabukuro; Smith, 1991). The model can be expressed as Equation 1 (Aguiar et al., 1999):

$$
r_{i}=\sum_{j=1}^{n}\left(a_{i j} x_{j}\right)+e_{i}
$$

where: $i=1, \ldots, m$ (number of spectral bands); $j=1, \ldots, n$ (number of components); $r_{i}=$ spectral reflectance of the $\mathrm{i}^{\text {th }}$ spectral band of a pixel which contains one or more components; $a_{i j}=$ known spectral reflectance of the ${ }_{\mathrm{j}}$ th component within the pixel on the $\mathrm{i}^{\text {th }}$ spectral band; $x_{j}=$ proportion value of the $\mathrm{j}^{\text {th }}$ component within the pixel; and $e_{i}=$ error for the $\mathrm{i}^{\text {th }}$ spectral band.

b) Image segmentation: is the technique to segment the image in homogeneous regions by defining two thresholds: similarity and area. Similarity is the minimum threshold for which two adjacent areas are considered similar and grouped into one region and area is the minimum size given by the number of pixels to individualize one region (Bins et al., 1996).

c) Unsupervised classification by region: is performed using the ISOSEG classifier (Bins et al., 1993). This algorithm uses the covariance matrix and mean vector of the regions to estimate the center of each class. The acceptance threshold which is the maximum Mahalanobis distance is used to define if the pixel belongs or not to a specific class.

d) Manual edition: is performed to reduce the commission and omission errors increasing the map accuracy (Almeida Filho; Shimabukuro, 2002). It is necessary to perform this laborious task due to errors in the digital image classification and it is highly dependent on the interpreter experience. 


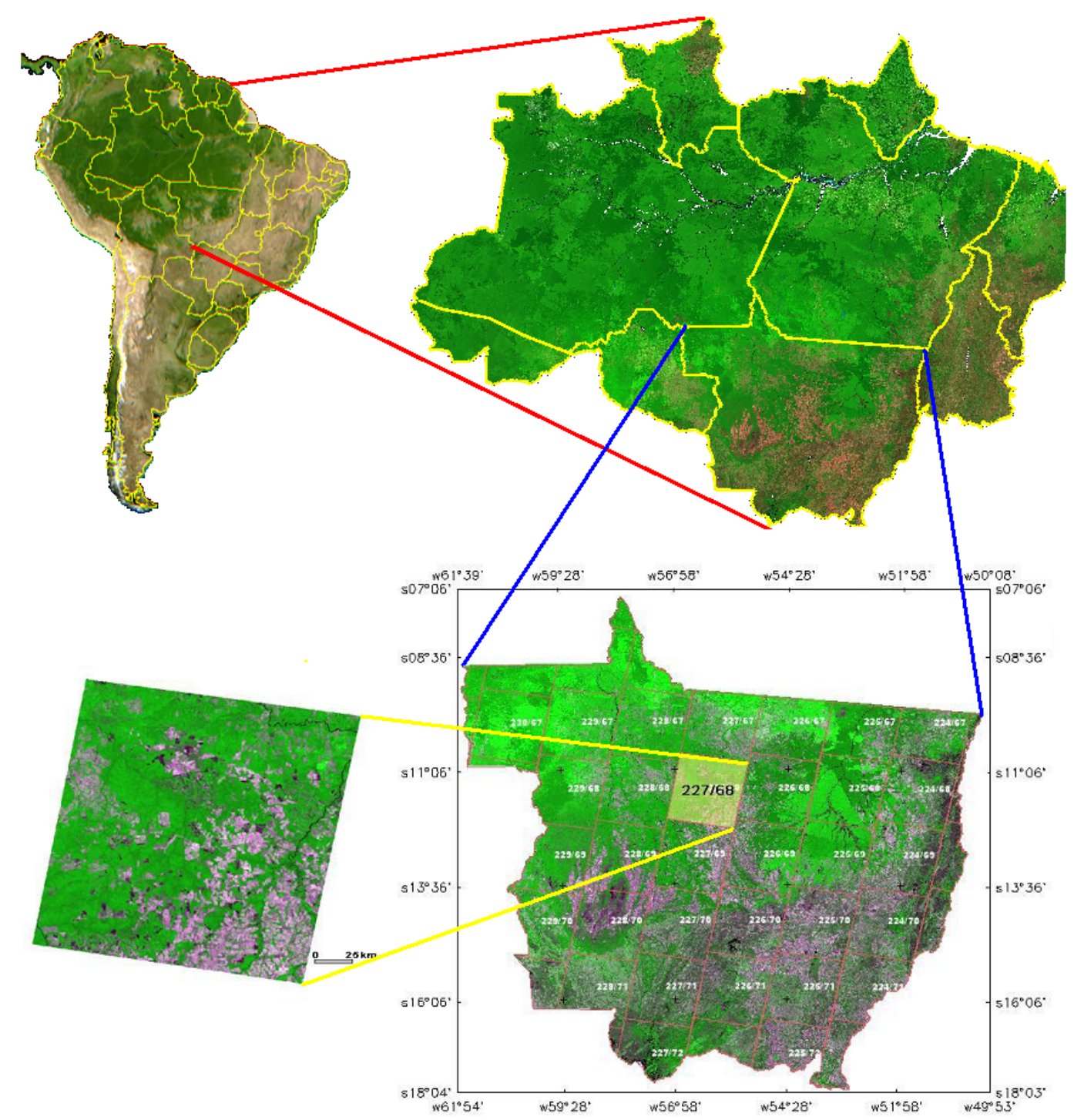

Figure 1. DETER study area: Brazilian Amazon showed by a MODIS image mosaic (R(MIR), G(NIR), B(Red)) from 12 to 27 August 2003 and test site located in Mato Grosso State corresponding to the Landsat Path 227 Row 68.

\subsection{Evaluation and Validation}

To evaluate the near real time deforestation detection proposed procedure a multitemporal series of MODIS surface reflectance images (MOD09) and the corresponding ETM+ images from June to October 2002 were analyzed (Anderson et al., 2005). The eight Landsat ETM+ images were registered and radiometricaly rectified (Justice et al., 2002) for the temporal land cover change analysis (Lillesand; Kiefer, 1994).

The Linear Spectral Mixing Model (LSMM) was applied separately for both MODIS and ETM + datasets using 3 endmembers selected directly from the images: vegetation, soil, and shade. For the MODIS dataset seven spectral bands were used: blue (470 nm), green (555 $\mathrm{nm})$, red $(648 \mathrm{~nm})$, near infrared $(858 \mathrm{~nm})$ and middle infrared $(1240 \mathrm{~nm}, 1640 \mathrm{~nm}$, and 2130 $\mathrm{nm}$ ). The two first bands have $250 \mathrm{~m}$ of spatial resolution while the other five bands have 500 $\mathrm{m}$ of spatial resolution which were resampled to $250 \mathrm{~m}$. For the ETM+ dataset all bands except the thermal band were used. The resulting soil fraction images highlight the contrast between forested and clear cut areas being the primary source of information in this study. 
A single mask of deforested areas prior to 2002, for both dataset (MODIS and ETM+), was obtained from the PRODES project for the year of 2001. The detection procedure was performed starting with the image of Julian day 166 (15 June) and followed by the images of Julian days: 182 (01 July), 198 (17 July), 214 (02 August), 230 (18 August), 246 (03 September), 262 (19 September), and 278 (05 October). The validation of the deforestation detection using MODIS was performed by comparing this result with both deforestation detected on the corresponding Landsat scenes and field work.

\subsection{DETER - Operational Procedure}

The described procedure was applied to detect deforested areas in the year of 2004 for the entire Brazilian Amazon (DETER). For this, a mask of old deforestation (prior to 2003) and non-forested areas was produced. The information from the PRODES for the year 2003 was matched with the MODIS image mosaic of 2003 in order to separate the remaining primary forest cover over which the new deforested areas in 2004 should be detected. This detection was performed using a multitemporal sequence of almost cloud free selected MODIS images acquired on 07 May, 21 May, 08 June, 29 June, 29 July, and 25 August 2004.

To exemplify the operational procedure of the DETER project a region in Mato Grosso State using two MODIS images acquired on 07 and 21 May 2004 was selected (Figure 2). Figure 2a shows the PRODES mask over the MODIS image of August 2003. This mask prevents the detection of old deforested areas over the first image of the multitemporal MODIS dataset. The mask shows old deforested areas in yellow and non-forested areas in pink, as defined by the PRODES project (INPE, 2002). Figure $2 \mathrm{~b}$ shows the same mask over the first MODIS image acquired in 2004 (07 May 2004) where the new deforested areas between August 2003 and 07 May 2004 appear in magenta, contrasting with the green appearance of forested cover in the RGB colour composite (MIR, NIR and Red). Figure 2c shows in black these new deforested areas that were classified using the previously described method. To continue the process of detection of deforested areas the new mask (yellow plus black) was overlaid on the subsequent MODIS image acquired on 21 May 2004. Then the new deforested areas were classified on this image and are depicted in red on Figure $2 \mathrm{~d}$. This sequence continues until the last cloud free MODIS image was analyzed in 2004 (25 August).

A field work was carried out in July 2004 in central Mato Grosso State to verify the agreement between the deforested areas detected on the MODIS images with this procedure and the observed deforested areas in the field. The observed areas were selected based on the extensive network of unpaved roads in central Mato Grosso. To accurately locate these areas in the field Landsat/TM images and GPS were used. 


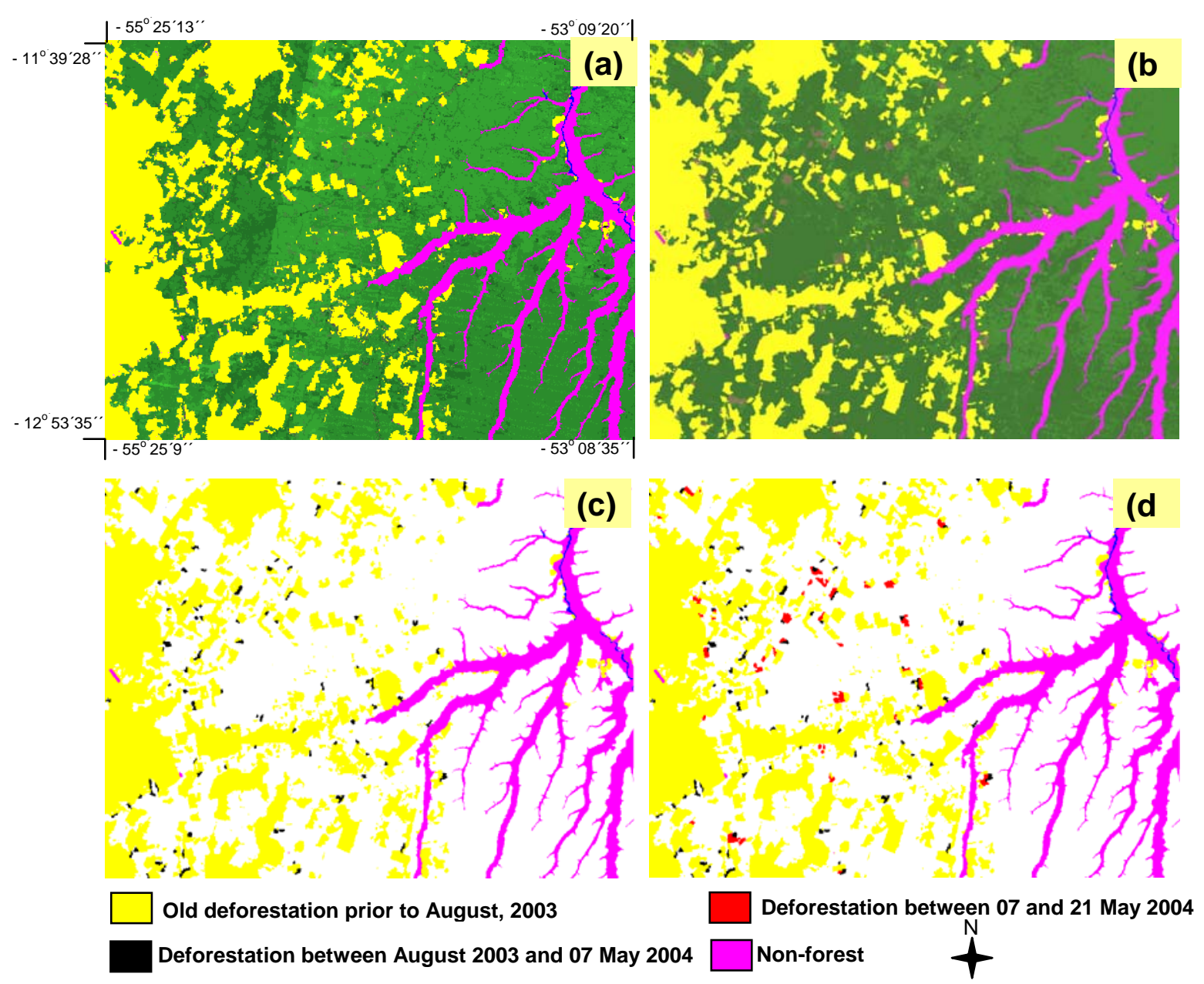

Figure 2. Operational procedure of the DETER project over a selected region in Mato Grosso State: (a) MODIS image from August 2003 without any new deforestation and the mask of old deforestation prior to August 2003 (yellow) and non-forested areas (pink); (b) MODIS image from 07 May 2004 with new deforested areas occurred between August 2003 and 07 May 2004; (c) Classified deforested areas (black) between August 2003 and 07 May 2004; (d) Classified deforested areas (red) between 07 and 21 May 2004.

\section{RESULTS AND DISCUSSION}

\subsection{Evaluation and Validation}

Figure 3 presents the number of deforested areas detected by both MODIS and ETM+ sensors over the test site (Figure 1). The deforested areas were stratified according to their size into three classes: (a) less than 15 ha; (b) between 15 and 50 ha; and (c) between 50 and 100 ha. Figure $3 \mathrm{a}$ indicates that small deforested areas (less than $15 \mathrm{ha}$ ) were very difficult to be detected with MODIS images. For areas between 15 and 50 ha, as illustrated in Figure 3b, the MODIS images detected deforested areas with low accuracy. However, for areas greater than 50 ha the MODIS images detected deforested areas as well as the Landsat images as shown in Figure 3c. Therefore, as the size of the deforested areas increases MODIS and ETM+ results tend to converge. But it is important to point out that the objective of this procedure is to detect near real time deforested areas and not to provide a quantitative annual evaluation of deforestation rate which is performed by the PRODES project. It should be pointed out that the area estimation figures were used to facilitate the evaluation of the 
MODIS results as presented in Figure 3. Therefore, the deforested area estimation with MODIS data should be used with caution.
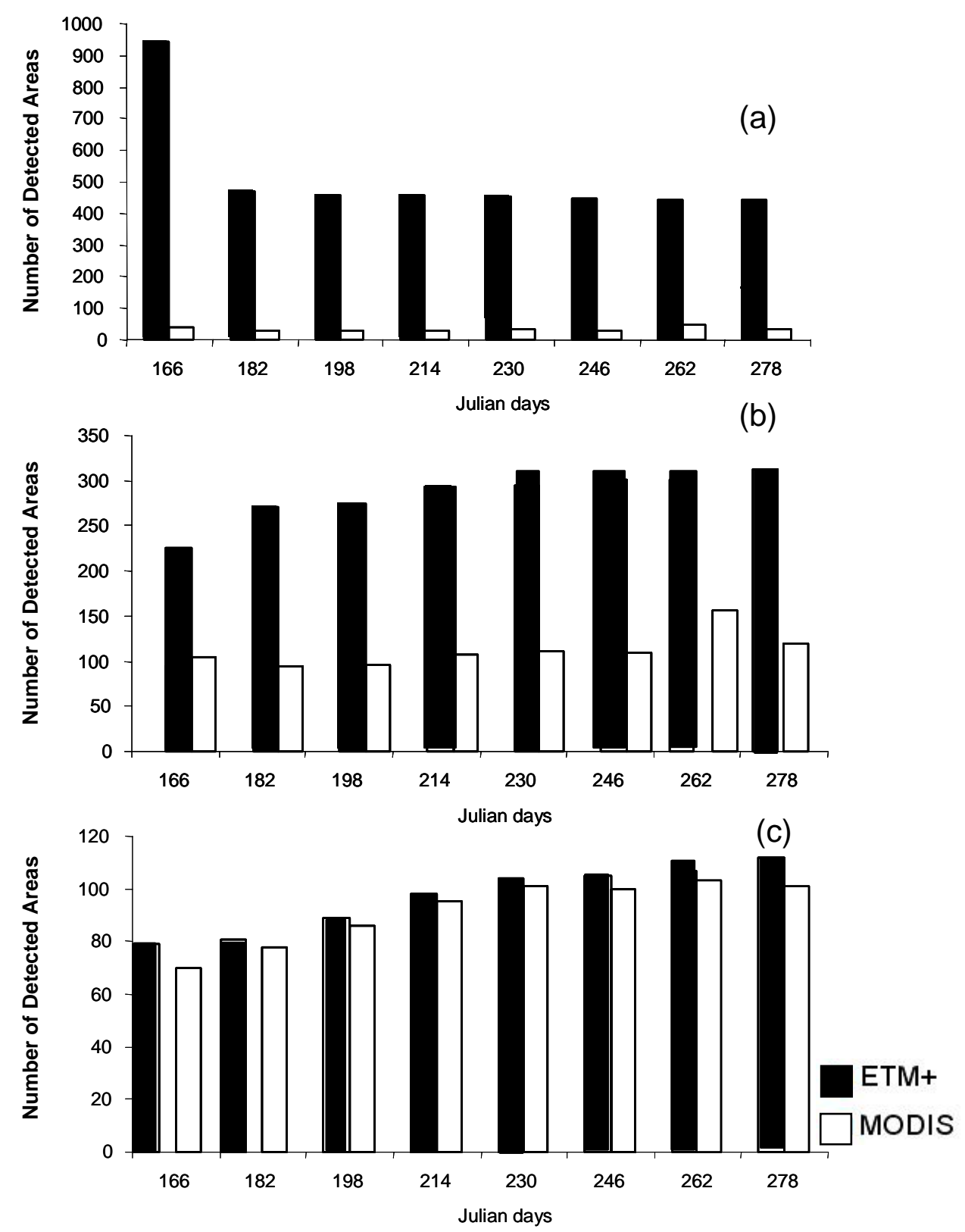

Figure 3. Number of deforested areas, detected by both MODIS and ETM+ sensors, stratified into three size classes: (a) less than 15 ha; (b) between 15 and 50 ha; and (c) between 50 and 100 ha.

Figure 4 shows the spatial distribution of the deforested areas sequentially detected by the MODIS multitemporal dataset in the test site (Figure 1). This multitemporal analysis was successfully performed due to the high geometric quality of the MODIS dataset. 


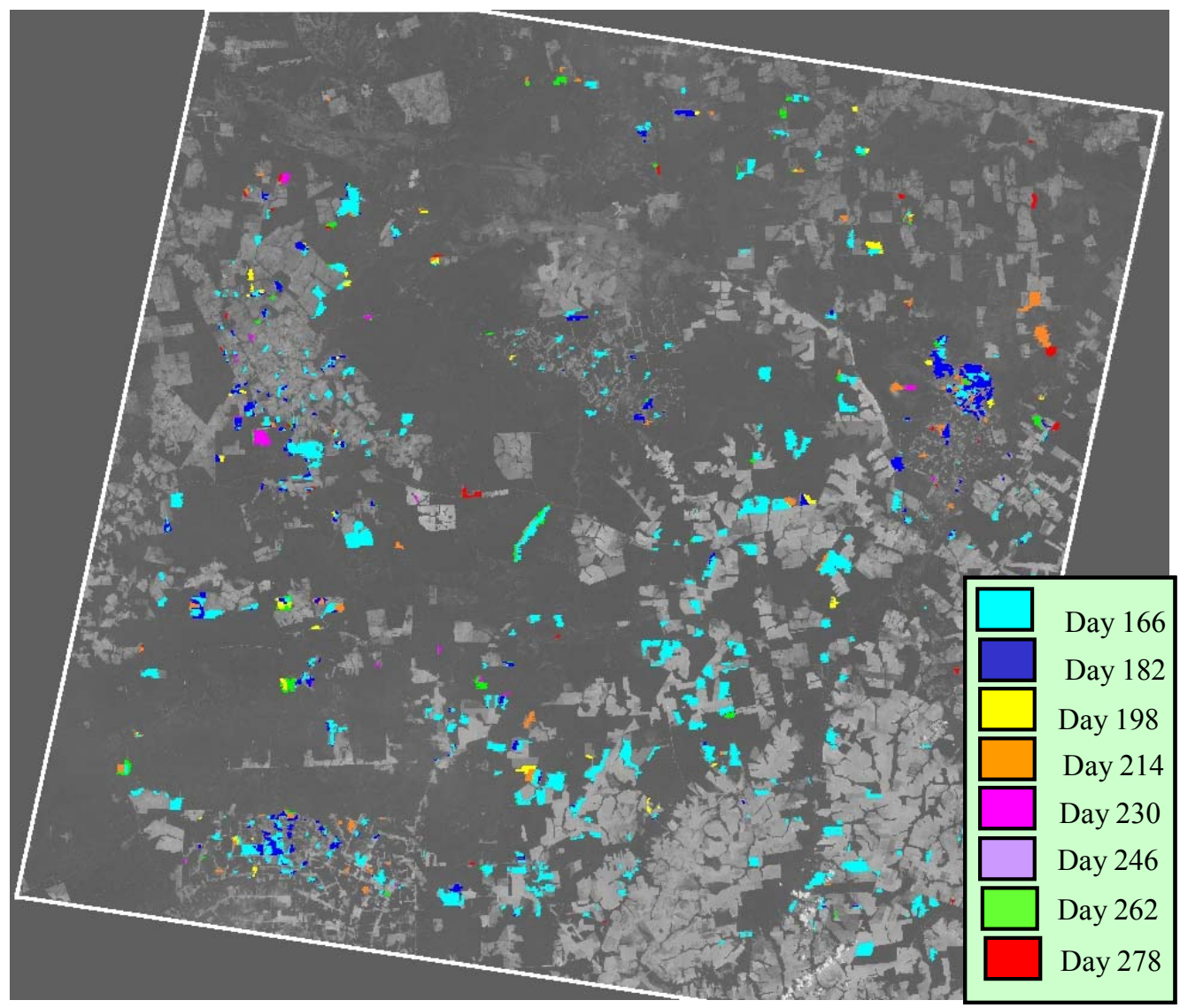

Figure 4. Time sequence of deforested areas detected on the multitemporal MODIS dataset in the test site.

\subsection{DETER - Operational Procedure}

Based on the results obtained for the test site and considering the objective of the DETER project the present procedure was applied for the entire Brazilian Amazon region using a sequence of multitemporal MODIS images acquired during the year of 2004.

Table 1 shows the deforested areas detected from August 2003 (base date) through 25 August 2004 for each State in the Brazilian Amazon. As can be observed in Table 1 the deforested areas for the first image (07 May 2004) present $1,573.3 \mathrm{~km}^{2}$ which correspond to the deforested area between the period of August 2003 and 07 May 2004. Major deforestation was observed in Mato Grosso State representing almost $50 \%\left(10,151.7 \mathrm{~km}^{2}\right)$ of the entire deforestation in the Brazilian Amazon over the analyzed period. Although a high increase in deforested area is observed for the period between 08 and 22 June (14 days) this estimation should be analyzed with caution due to the fact that the deforested areas are detected only under cloud free conditions. This means that some areas were detected only on specific dates due to previous cloud cover.

Some detected deforested areas were visited during field work in Mato Grosso State where most deforestation occurred in 2004. It was noticed that fields greater than two pixels of MODIS were detected with high accuracy confirming the feasibility of the proposed procedure. 
Table 1. Deforested areas in $\mathrm{km}^{2}$ detected in the August 2003 to August 2004 time period.

\begin{tabular}{l|r|r|r|r|r|r|r}
\hline \multicolumn{1}{c|}{ STATES } & May 07 & May 21 & June 08 & June 22 & July 29 & August 25 & TOTAL \\
\hline Acre & 0.0 & 0.0 & 9.9 & 0.0 & 112.0 & 334.5 & 456.4 \\
Amapá & 0.0 & 0.0 & 0.0 & 0.0 & 0.0 & 0.0 & 0.0 \\
Amazonas & 0.0 & 0.0 & 13.0 & 367.7 & 335.3 & 177.9 & 893.9 \\
Maranhão & 1.3 & 0.0 & 0.0 & 2.7 & 0.0 & 0.0 & 4.0 \\
Mato Grosso & $1,471.9$ & $1,679.4$ & $1,158.5$ & $3,641.2$ & 878.3 & $1,322.4$ & $10,151.7$ \\
Pará & 97.9 & 168.8 & 105.6 & $4,054.7$ & $1,828.1$ & 560.8 & $6,815.9$ \\
Rondônia & 0.0 & 0.0 & 133.0 & 529.8 & $1,260.0$ & 676.6 & $2,599.4$ \\
Roraima & 0.00 & 0.0 & 0.0 & 0.0 & 0.0 & 0.0 & 0.0 \\
Tocantins & 2.2 & 1.6 & 0.0 & 64.2 & 0.0 & 0.0 & 68.0 \\
\hline Amazônia & $\mathbf{1 , 5 7 3 . 3}$ & $\mathbf{1 , 8 4 9 . 8}$ & $\mathbf{1 , 4 2 0 . 0}$ & $\mathbf{8 , 6 6 0 . 3}$ & $\mathbf{4 , 4 1 3 . 7}$ & $\mathbf{3 , 0 7 2 . 2}$ & $\mathbf{2 0 , 9 8 9 . 3}$ \\
\hline
\end{tabular}

The spatial distribution of the detected deforested areas presented in Table 1 is available and can be accessed through the Internet site (http://www.obt.inpe.br/deter/). Since this information is into a GIS the detection of deforested areas in the Brazilian Amazon can be obtained by State, municipality, and others. The primary use of this information is to monitor the deforestation activities. This procedure showed to be adequate to detect and monitor deforested areas in near real time and has been continuously used on an operational base since 2004 being part of a government plan to control the Amazon deforestation (Shimabukuro et al., 2005).

\section{CONCLUSIONS}

The MODIS sensor with moderate spatial resolution, high geometric quality and daily observation is feasible for detection of near real time deforestation in the Brazilian Amazon. Small deforested areas (lower than 15 ha) were detected by MODIS images with lower accuracy when compared with ETM+ images. However, this procedure showed to be adequate to operationally detect deforested areas in near real time and has been used since 2004 as part of a government plan to control the Amazon deforestation.

\section{ACKNOWLEDGMENTS}

This research was partially supported by FAPESP grant (Proc. 2003/01727-0). The authors also like to thank the LBA-LC 22 for the field work support.

\section{REFERENCES}

AGUIAR, A. P. D.; SHIMABUKURO, Y. E.; MASCARENHAS, N. D. A. Use of synthetic bands derived from mixing models in the multispectral classification of remote sensing images. International Journal of Remote Sensing, London, v. 20, p. 647-657, 1999.

AGUIAR, A. P. D, SHIMABUKURO, Y. E.; MASCARENHAS, N. D. A. Use of synthetic bands derived from mixing models in the multispectral classification of remote sensing images. International Journal of Remote Sensing, London, v. 20, p. 647-657, 1999. 
ALMEIDA FILHO, R.; SHIMABUKURO, Y. E. Digital processing of a Landsat-TM time series for mapping and monitoring degraded areas caused by independent gold miners, Roraima State, Brazilian Amazon. Remote Sensing of Environment, New York, v. 79, p. 42-50, 2002.

ANDERSON, L. O.; SHIMABUKURO, Y. E.; DEFRIES, R. S.; MORTON, D. Assessment of deforestation in near real time over the Brazilian Amazon using multitemporal fraction images derived from Terra MODIS. IEEE Geoscience and Remote Sensing Letters, Piscataway, n. 2, n. 3, p. 315-318, 2005.

BARTHOLOMÉ, E.; BELWARD, A. S. GLC2000: a new approach to global land cover mapping from Earth observation data. International Journal of Remote Sensing, London, v. 26, n. 9, p. 1959-1977, 2005.

BINS, L. S.; ERTHAL, G. J.; FONSECA, L. M. G. Um método de classificação nãosupervisionada por regiões. In: BRAZILIAN SYMPOSIUM ON GRAPHIC COMPUTATIONAL AND IMAGE PROCESSING, 6., 1993, Recife. Proceedings... Rio de Janeiro: Gráfica Wagner, 1993. p.65-68.

BINS, L. S.; FONSECA, L. M. G.; ERTHAL, G. J. Satellite imagery segmentation: a region growing approach. In: SIMPÓSIO BRASILEIRO DE SENSORIAMENTO REMOTO, 8., abr. 1996, Salvador. Anais... São José dos Campos: INPE, 1996.

CARREIRAS, J. M. B.; SHIMABUKURO, Y. E.; PEREIRA, J. M. C. Fraction images derived from SPOT-4 VEGETATION data to assess land-cover change over the State of Mato Grosso, Brazil. International Journal of Remote Sensing, London, v. 23, p. 4979-4983, 2002.

DEFRIES, R. S.; HANSEN, M. C.; TOWNSHEND, J. R. G. Global continuous fields of vegetation characteristics: a linear mixture model applied to multi-year $8 \mathrm{~km}$ AVHRR data. International Journal of Remote Sensing, London, v. 21, p. 1389-1414, 2000.

. Global land cover classifications at $8 \mathrm{~km}$ spatial resolution: the use of training data derived from Landsat imagery in decision tree classifiers. International Journal of Remote Sensing, London, v. 19, p. 3141-3168, 1998.

INSTITUTO NACIONAL DE PESQUISAS ESPACIAIS. Deforestation estimates in the Brazilian Amazon. São José dos Campos: INPE, 2002. Available at: $<$ http://www.obt.inpe.br/prodes/>. Accessed in june 2003.

JUSTICE, C. O.; TOWNSHEND, J. R. G.; VERMOTE, E.; WOLFE, R.; EL SALEOUS, N.; ROY, D. An overview of MODIS Land data processing and product status. Remote Sensing of Environment, New York, v. 83, p. 3-15, 2002.

LILLESAND, T. M; KIEFER, R. W. Remote sensing and image interpretation. New York: John Wiley \& Sons, 1994. 724p.

SHIMABUKURO, Y. E.; BATISTA, G. T.; MELLO, E. M. K.; MOREIRA, J. C.; DUARTE, $\mathrm{V}$. Using shade fraction image segmentation to evaluate deforestation in Landsat TM and MSS data for monitoring reforested areas. International Journal of Remote Sensing, London, v. 19, p. 535-541, 1998. 
SHIMABUKURO, Y. E.; DUARTE, V.; MOREIRA, M. A.; ARAI, E.; RUDORFF, B. F. T.; ANDERSON, L. O. et al. Detecção de áreas desflorestadas em tempo real: conceitos básicos, desenvolvimento e aplicação do projeto DETER. São José dos Campos: INPE, 2005. 63p. (INPE-12288-RPE/796).

SHIMABUKURO, Y. E.; SMITH, J. A. The least-squares mixing models to generate fraction images derived from remote sensing multispectral data. IEEE Transactions on Geoscience and Remote Sensing, Piscataway, v. 29, p. 16-20, 1991.

TOWNSHEND, J.; JUSTICE, C.; LI, W.; GURNEY, C.; MCMANUS, J. Global land cover classification by remote sensing: present capabilities and future possibilities. Remote Sensing of Environment, New York, v. 35, p. 243-255, 1991.

VERMOTE, E. F.; EL SALEOUS, N. Z.; JUSTICE, C. O. Atmospheric correction of MODIS data in the visible to middle infrared: first results. Remote Sensing of Environment, New York, v. 83, p. 97-111, 2002. 